\title{
LUKISAN PRASEJARAH GUA LEANG-LEANG KABUPATEN MAROS, SULAWESI SELATAN: KAJIAN SIMBOL S. K. LANGER
}

\author{
Muhammad Gazali \\ Program Pascasarjana, Universitas Negeri Semarang \\ E-mail: gazalimandar@gmail.com
}

\begin{abstract}
Abstrak
Lukisan di gua Leang-Leang merupakan salah satu artefak budaya sebagai bukti kekayaan dan simbol peradaban manusia. Lukisan merupakan abstraksi ide-ide, religi mitis, dan sumber pandangan hidup masyarakat prasejarah. Makna simbol lukisan mampu membongkar dan menjelaskan ideide tentang religi, interaksi sosial, estetik, dan pandangan hidup masyarakat prasejarah. Melalui teori estetika simbolis S. K. Langer merupakan simbol ekspresi. Karya seni merupakan simbol seni secara khusus. Lukisan prasejarah gua Leang-Leang sebagai karya seni merupakan simbol seni itu sendiri. Lukisan merupakan simbol presentasional, makna simbolnya harus dilihat dari keseluruhan bukan parsial. Bentuk ekspresi inilah disebut karya seni yang merupakan proyeksi dari gejolak perasaan. Lukisan prasejarah gua Leang-Leang adalah virtual space, atau gambaran dari mitos-mitos yang dipercayai dalam kehidupan masyarakatnya.
\end{abstract}

Kata Kunci: lukisan, gua Leang-Leang, S.K. Langer, simbol

\section{S.K LANGER SYMBOL ANALYSIS OF PREHISTORIC PAINTINGS IN LEANG-LEANG CAVE IN MAROS REGION, SOUTH SULAWESI}

\begin{abstract}
Paintings in the Leang-Leang caves is one of the cultural artifacts and the evidence of richness and symbol of human civilization. These paintings are the abstract ideas of religious, mythical, and source of prehistoric society. Meaning of the symbols of painting could break down and explain ideas about religion, social interaction, aesthetic and way of life of prehistoric people. Through the symbolic aesthetic theory S. K. Langer who thinks art is a symbol of expression. The work of art is a symbol of art in particular. Prehistoric cave paintings Leang-Leang as a work of art is a symbol of art itself. Painting is a presentational symbol, the meaning of the symbol should be seen from a whole rather than partial. This is a form of expression called a work of art which is a projection of emotional rollercoaster. Prehistoric cave paintings Leang-Leang is a virtual space, or the depiction of myths believed in the life of society.
\end{abstract}

Keywords: paintings, Leang-Leang, cave, S. K. Langer, symbol

\section{PENDAHULUAN}

Gua merupakan tempat hidup bagi manusia prasejarah, mereka memilih gua karena gua dianggap tempat yang paling cocok untuk menghindari serangan dari binatang-binatang buas yang ada di luar (alam bebas). Gua menjadi tempat menciptakan tatanan masyarakat pada zaman prasejarah, menciptakan budayanya dan juga sebagai tempat terciptanya komunikasi sosial antara mereka. Hal ini dapat dilihat dari beberapa peninggalan yang ditemukn didalam gua yang tersebar dimanca Negara, seperti di Spanyol, Afrika dan Australia. Peninggalan yang paling muda ditemui berupa bekas hasil dapur 
yang telah menyatu dan menjadi batu, dan juga tentunya sebuah lukisan yang berbentuk tangan dan berbentuk hewan, dapat dikatakan bahwa lukisan gua tersebut sebagai bentuk seni pertama yang telah diciptakan oleh manusia. Lukisan prasejarah juga telah menjadi peninggalan yang ada di gua-gua Indonesia, persebaran lukisan prasejarah tersebut tersebar di berbagai daerah seperti di Kepulauan Maluku, Papua, Kalimantan, dan Sulawesi Selatan.

Daerah Sulawesi Selatan memiliki sejarah yang panjang, baik yang bersifat lokal maupun nasional, dengan berbagai peninggalannya. Peristiwa pembunuhan massal (40.000.000 jiwa) oleh Westerling (selanjutnya disebut sebagai "Peristiwa Westerling") misalnya, peristiwa itu tidak akan terlupakan, khususnya oleh orang Sulawesi Selatan dan umumnya masyarakat Indonesia. Sulawesi Selatan tampaknya tidak hanya menyimpan berbagai peninggalan sejarah, tetapi berbagai peninggalan prasejarah. Peninggalan-peninggalan itu (berupa artefak) yang terdapat di berbagai gua yang ada di sana, salah satu diantaranya adalah lukisan-lukisan yang terdapat pada dinding-dinding gua.

Tanah Sulawesi Selatan telah ikut menggemparkan dunia seni (seni rupa), terutama dengan ditemukannya beberapa lukisan di gua-gua yang ada di kabupaten Maros dan Pangkep, usia lukisan prasejarah yang berada di kabupaten Maros dan Pangkep itu diperkirakan telah berumur 30-an ribu tahun. Suatu usia yang telah sangat tua dibanding dengan usia lukisan prasejarah di Erofa dan Afrika. Penemuan lukisan gua di Sulawesi Selatan untuk pertama kalianya dilakukan oleh C.H.M. Heeren-Palm pada tahun 1950 di Leang Pattae, walaupun memang tidak menutup kemungkinan bahwa masyarakat sekitar sudah mengenal jauh sebelum itu. Di gua ini ditemukan cap-cap tangan dengan latar belakang cat merah. Barangkali ini merupakan cap tangan kiri perempuan. Ada pun cap-cap tangan tangan ini dibuat dengan cara merentangkan jari-jari tangan itu di dinding gua kemudian ditaburi dengan cat merah. Di gua tersebut juga ditemukan lukisan seekor babi rusa yang sedang melompat dengan panah di bagian jantungnya. Lukisan semacam ini dimaksudkan sebagai suatu harapan agar mereka berhasil berburu di dalam hutan. Babi rusa tadi digambarkan dengan garis-garis horizontal bewarna merah.

Beberapa ahli berpendapat bahwa tujuan dari pembuatan lukisan Gua itu berkaitan dengan kepercayaan yang bersifat religius dan dibuat tidak semata-mata hanya berkaitan dengan nilai artistik atau untuk sekedar untuk tujuan keindahan. Lukisan-lukisan gua prasejarah itu memiliki kaitan sebagai bagian dari usaha manusia pada masa lalu agar dapat melakukan komunikasi dengan alam dan kekuatan yang sifatnya supranatural. Ada juga yang memperkirakan lukisan gua prasejarah pada awalnya adalah bentuk permohonan yang ditujukan kepada kekuatan yang mereka percayai dapat mengabulkannya (doa). Lukisan cap tangan pada dinding gua bagi Van Heekeren, itu berhubungan dengan sebuah ritual kelahiran, kematian dan juga menggambarkan sebuah perjalanan dari arwah yang tengah merabaraba untuk menuju ke alam yang selanjutnya. Di samping itu, Lukisan cap tangan dapat juga dimaknai sebagai tanda berbelasungkawa atas kematian sanak saudara.

Salomon Reinach seorang arkeolog Prancis yang meneliti agama dan seni Palaeolitik. menawarkan sebuah konsep sympathetic magic, ritual menggunakan objek magis atau tindakan simbolis terkait dengan peristiwa atau orang yang lebih berpengaruh. Hunting magic, keyakinan tentang akan adanya kekuatan ketika berburu. Dan fertility magic, yaitu keyakinan tentang adanya sebuah kekuatan yang berkaitan dengan kesuburan. Lukisan gua dengan jenis kelamin wanitanya yang tegas, jika menggunakan konsep Sympathetic Magic dapat dihubungkan dengan konsepsi kesuburan yang menjadi harapan. Manusia pada masa lalu hingga sekarang senantiasa mencari cara untuk meningkatkan kesuburan, baik itu yang berhubungan dengan alam atau dalam hal keturunan. Kesuburan adalah sebuah makna umum yang menjadi indikator keberlangsungan hidup manusia di dunia.

Sementara itu Begeuen, menganalisis dari segi rites magic. Begeuen percaya 
bahwa lukisan-lukisan gua prasejarah itu mempunyai ikatan dengan ritual atau upacara yang berhubungan dengan dunia magis. Konsepsi rites magic ini mencoba menjelaskan bahwa manusia pada masa lalu senantiasa mengadakan upacara atau ritual yang berkaitan dengan kepercayaan atau keyakinan pada kekuatan yang dianggap menguasai semua hal yang berada di luar kemampuan mereka. Pada intinya, rites magic berusaha untuk menunjukan bahwa manusia pada masa lalu itu senantiasa berusaha menujukan bentukbentuk dari sebuah kepercayaannya dengan mengabadikan berbagai hal. Lukisan pada zaman prasejarah dianggap rites magic, sebagai simbol kepercayaan pada yang transenden dan yang kudus. Simbol merupakan suatu cara untuk dapat sampai pada pengenalan akan yang kudus dan yang transenden (Sutanto, 1987:61). Simbol memperluas penglihatan tentang realitas transenden, bersamaan dengan itu, simbol memperluas roh manusia untuk memampukannya ditangkap oleh penglihatan itu sehingga tumbuh berkembanglah pengertian rohaninya (Dillistone, 2002:125).

Secara umum kegiatan manusia melibatkan simbolisme, oleh sebab itu manusia dijuluki bukan saja animal rationale melainkan juga animal symbolicum makhluk yang bermain dengan simbol-simbol (Cassirer, 1990:40). Hanya dengan menggunakan simbol-simbol, manusia dapat mencapai potensi dan tujuan hidupnya yang tertinggi. Simbol merupakan alat yang kuat untuk memperluas penglihatan manusia, merangsang daya imajinasi, dan memperdalam pemahamannya. Data keinderawian manusia pertama-tama adalah simbol-simbol (Langer dalam Sagari, 2007:21).

Menggunakan simbol secara penuh berarti menjadi lebih manusiawi. Bentuk gerakan, teriakan, goresan, pahatan dan susunan batu yang dilakukan manusia menjadi luhur ketika menjadi simbolis. Bentuk simbolis yang diaktualisasikan dari ungkapan atau luapan emosi menjadi alat komunikasi untuk berinteraksi dengan orang lain atau untuk angkatan yang akan datang (Saragi, 2007:23).
Sussanne K. Langger lahir pada tahun 1895. Ia mendapatkan gelar sarjanannya dari Radcliffe College, Cambridge, Massachussetts pada tahun 1920, kemudian ia mendapatkan gelar master dan doctor dalam bidang filsafat dari Harvard pada tahun 1924 dan 1926. Selama 15 tahun kemudian, Langger mengajar filsafat di beberapa tempat, di antaranya Radcliffe, Welleley, Smith dan juga tempat beberapa tempat lainnya. Langger juga merupakan seorang professor dalam bidang filsafat di Connecticut College di New London. Ia pensiun dengan hormat pada tahun 1962 (Turner, 1996:739).

Buku pertama yang ditulis oleh Langger yaitu studi mengenai khayalan dan mitos, the cruise of the little dipper, and other fairy tales (1924). Sedangkan buku filsafat pertamanya adalah the practice of philosophy (1930) dan an introduction to symbolic logic (1937). Sussane Langger menjadi seorang figur pemimpin dalam dunia filsafat seni dengan dipublikasikannya buku philosophy in a new key: a study in the symbolism of reason, rite and art (1942) dan language and myth (1946) yang merupakan terjemahannya dari karangan seorang filsuf Jerman, Ernst Cassirer. Pada tahun 1945-1950 ia mengajar di Columbia Uneversity di mana ia mendapat dana bantuan dari Rockefeller Foundation untuk menulis buku feeling and form: a theory of art (1953). Langger menghabiskan tahun terakhir dari hidupnya dengan tinggal di rumahnya yang bergaya Colonial di Old Lyme dimana ia mengabdikan dirinya untuk menulis tiga edisi Mind: an essay on human feeling (1967, 1972, dan 1982) yang merupakan puncak dari kehidupan karyanya (Ali, 2011:113).

Susssane Langer merupakan filsuf perempuan kelahiran Amerika Serikat. Kesenian menjadi salah satu bidang pengamatannya. Menurut Langer (dalam Ali, 2011:114), seni memiliki logikanya sendiri, yakni logika simbolis yang mampu masalah etis secara khas. Estetika dapat menjadi jalan masuk ke bidang etika. Pendekatan Langer cukup meyakinkan. Ia bertolak dari studio-studio dimana para seniman bekerja. Ia tidak merumuskan konsepkonsep seni dari galeri-galeri di mana karya seni dipamerkan, karena ini kurang mencerminkan 
pengalaman bagaimana sebuah karya seni dilahirkan. Dia terkenal karena banyak hal, termasuk pemikirannya tentang filsafat, puisi, musik dan bahasa.

Nama Sussane Langer mulai dikenal ketika buku philososphy in a new key terbit pada 1942. Buku ini mengejutkan orang-orang, karena teori simbol dan pemisahan diri yang tegas dari tradisi filsafat Neo-Positivisme yang menjadi panutan umum pada masa itu. Karya Langer memperlihatkan penyelidikan yang luas dan juga pengamatan terhadap pengamatan terhadap pengalaman manusia.

Sussane Langer memulai kariernya dari latar belakang filsafat Neo-Positivisme. Dia tidak tertarik pada metafisika, tetapi pada bagaimana cara metafisika itu disampaikan atau pada bahasa metafisika itu sendiri. Perhatiannya lebih mengarah pada permasalahan simbol dan ciri-ciri diskursivitas. Sussane Langer memperhatikan bahwa simbol tidak hanya digunakan dalam bidang logika saja, yakni: logika simbol, tetapi juga dalam bidang-bidang yang amat berbeda. Bidang-bidang ilmu yang menggunakan simbol-simbol adalah musik, ilmu kimia, statistik dan psikoanalisis. Misalnya, 'teori mimpi' yang dikembangkan oleh Sigmund Freud dan Car Gustav Jung dalam psikoanalisis adalah salah satu contoh penggunaan simbol yang tidak diskursif (Ali, 2011:115)

Pertama-tama Sussane Langer membedakan antara tanda dan simbol. Tanda (sign) dipakai untuk menyatakan suatu hal, peristiwa atau keadaan. Tanda merujuk pada objeknya, artinya antara tanda dan objek terjalin suatu hubungan. Dan biasanya tanda merangsang subjek, si penangkap tanda untuk bertindak. Sebuah nama 'menunjuk' (denote) pada sesuatu, misalnya James. Walaupun memang James dapat mewakili sebuah konsep. Ada dua macam tanda, yakni: tanda alamiah dan tanda buatan. Contoh: asap (tanda alamiah); bunyi peluit (tanda buatan).

Kemudian simbol (symbol) merupakan wahana (vehicles) bagi konsepsi manusia tentang objek. Simbol lebih merupakan suatu representasi mental sang subjek. Sifatnya tidak selalu merangsang subjek untuk bertindak, namun membuat kita mencoba untuk memahaminya. Misalnya, bendera merah putih; nama diri, Sussane Langer. Hubungan antara tanda objeknya itu bersifat denotatif dan konotatif. Jadi hubungan simbol dan objeknya lebih dalam (subtil) dan lebih bermakna. Simbol otentik dapat juga berasal dari suatu objek, suara, atau tindakan yang tidak memiliki makna praktis, namun cenderung menimbulkan respons emosional, sehingga menarik perhatian orang.

Adapun simbol yang dimaksud ada dua macam, yaitu: simbol diskursif: adalah simbol yang rasional atau yang dapat dimengerti secara nalar. Hal ini terungkap jelas dalam bahasa dan juga dalam analisis pernyatan-pernyataan dalam logika. Simbol ini pengungkapannya secara bertahap dan dapat ditangkap oleh kemampuan akal-budi.

Kemudian simbol representasional, yakni simbol yang ditangkap tidak lewat intelek, tetapi secara spontan, dan intuitif langsung. Contoh: karya seni. Sebuah lukisan hanya dapat kita tangkap melalui arti keseluruhan, yaitu melalui hubungan antara elemen-elemen simbol dalam struktur keseluruhan.

Teori seni atau estetika Langer memang merupakan lanjutan dari studinya tentang simbol. Sussane Langer (Ali, 2011:116) beranggapan bahwa simbol merupakan seluruh kegiatan mental manusia. Kemajuan bahasa sebagai salah satu bentuk simbol diskursif. Tidak dapat disangkal telah menunjang kemajuan ilmu-ilmu lain. Bahasa merupakan wadah yang subur dimana ide-ide dilahirkan secara beruntun. Seni bukanlah merupakan deskripsi atau analisis fakta objektif seperti ilmu pengetahuan. Dalam seni selalu masih tertinggal subjektivitas seniman sebagai faktor penentu.

Menurut Sussane Langer, seni tidak mungkin didekati secara sekaligus. Kesenian yang bermacam-macam membutuhkan pendekatan secara sendiri-sendiri. Hal ini tidak berarti bahwa masing-masing kesenian mempunyai prinsip yang sama sekali lain, namun untuk memperoleh teori umum yang berlaku untuk semua seni, tidak ada jalan lain selain dengan melacak masing-masing prinsip yang berlaku untuk seni yang bersangkutan. Hanya dengan 
menelusuri batas-batas prinsip tunggal itulah titik pertemuan dari berbagai kesenian dapat ditentukan. Langer menunjuk prinsip kreasi seni, jenis konsepsi seni yang disebutnya sebagai 'forma yang hidup' (living form) dan ekspresi (Ali, 2011:117).

Prinsip kreasi itu sama, tetapi hasil dari seni itulah yang berlainan. Ekspresi seni juga satu dan sama, namun bentuk ekspresi dalam seni berlainan. Konsepsi seni secara umum adalah sama untuk setiap seni, namun isi dari konsepsi seni itu berlainan dan harus dikembalikan pada kekhasannya masing-masing. Filsafat harus melakukan observasi langsung ke kamar kerja seni yang bersangkutan.

Sussane Langer mendefinisikan seni sebagai "kreasi bentuk-bentuk simbolis perasaan manusia". Seni sebagai prinsip kreasi berlaku untuk semua macam kesenian. Definisi seni ini mengimplikasikan tiga hal:

a. Seni merupakan kreasi. Kreasi berarti pengadaan sesuatu yang tadinya tidak ada.

b. Rumusan bentuk simbolis. Bentuk simbolis dipertentangkan dengan isi atau materi dari simbol. Sebagai suatu bentuk simbolis seni itu sungguh sudah mengalami transformasi. Seni merupakan universalisasi dari pengalaman. Bentuk simbolis tidak menunjuk pada gejalanya sendiri atau pengalaman sendiri secara langsung melainkan pada pengalaman yang sudah disimbolkan yakni menjadi ungkapan simbolis dari pengalaman tersebut.

c. Bentuk simbolis yang dilemparkan seniman dalam kreasi seninya itu tidak berasal dari pikirannya melainkan dari perasaannya atau lebih tepat dikatakan sebagai formasi pengalaman emosionalnya. Bentuk simbolis yang berasal dari pikiran akan menghasilkan 'insight filosofis', namun jika berasal dari perasaan maka akan menghasilkan 'insight estetis'.

\section{PRINSIP PENCIPTAAN SENI}

Menurut Sussane Langer seni tidak mengulangi alam. Karena itu Langer menolak teori mimesis Plato yang mengatakan bahwa seni adalah tiruan, malah tiruan dari tiruan (mimesis-memeseos). Menurut Langer (dalam Sagari 2007:196), seni merupakan suatu kreasi atau penciptaan yang baru. Seni sungguhsungguh menghasilkan sesuatu yang lain sama sekali dari realitas alamiah. Pada seni terdapat prinsip 'kelainan' (otherness) dari realitas, yang membuat seni itu sungguh-sungguh berdiri sendiri sebagai ciptaan. 'kelainan' (otherness) ini adalah pelepasan dari aktualitas yang memberikan pada sebuah produk seperti seperti gedung atau sebuah pot, dan ini merupakan faktor menentukan yang menunjukkan kodrat seni yang sebenarnya. Jadi, dalam unsur unreality justru terletak kunci bagi masalah esensial dan mendalam, yakni: masalah kreativitas.

Simbolisasi dalam seni dilakukan lewat jalan abstraksi. Namun abstraksi ini tidak terjadi melalui generalisasi yang bertahap-tahap. Abstraksi pada seni merupakan abstraksi yang menyeluruh dan total karena bersifat kreatif dan bukan konstruktif.

Menurut Sussane Langer, dasar dari kreasi seni adalah apa yang disebutnya sebagai 'ilusi primer'. Ilusi primer adalah sebagai latar belakang penciptaan berbagai bentuk seni sebagai ilusi sekunder. Penciptaan kedua ilusi itu terjadi secara serentak. Jenis-jenis ilusi primer yang berbeda menghasilkan jenis karya seni yang berbeda:

a. Ruang virtual: seni plastis, misalnya seni lukis, seni pahat, dan arsitektur.

b. Waktu virtual: seni musik.

c. Daya virtual: seni tari.

d. Memori virtual: seni sastra.

Ilusi primer berbeda dari aktualitas. Kata 'virtual' dipakai justru untuk menunjukkan perbedaan antara ilusi primer dan aktualitas. Ruang waktu yang dimaksud bukanlah 'ruangwaktu' yang kita rasakan sedang berlangsung dan juga bukan ruang actual di mana bendabenda berada. Virtualitas ini terletak dalam konsepsi manusia. Virtualitas membuat ilusi primer terbuka bagi berbagai imajinasi yang bisa diciptakan oleh seniman. 


\section{KONSEPSI SENI SEBAGAI LIVING FORM}

Sussane Langer berpendapat bahwa seni sebagai living form memiliki ciri khas tersendiri, karena realitas yang diangkat kedalam simbol seni adalah realitas subjektif. Jadi, pengalaman subjektif dapat menjadi isu suatu bentuk simbolis. Jika pengalaman subjektif tersebut merupakan suatu perasaan yang kuat, maka pembentukan forma akan menunjukkan ekspresivitas yang kuat, sehingga forma itu tampak hidup. Contoh: bentuk dekorasi yang mengikuti pola tertentu, disebut 'desain'.

Prinsip bentuk simbolis yang hidup ini dapat dilihat dalam semua jenis kesenian. Simbol seni merupakan simbol ekspresif dan berkat ekspresivitas maka simbol seni tampak hidup. Karya seni merupakan ekspresi spontan dari perasaan. Seni juga mempunyai nilai edukatif karena seni menyimpan konsepsi keindahan dan menanamkan konsepsi ini ke dalam perasaan manusia.

\section{EKSPRESI DAN SENI}

Ekspresi merupakan unsur yang terkait erat dengan pemahaman simbolisasi seni. Mengapa? Karena simbol seni adalah simbol ekspresi manusia dan ekspresivitas inilah yang membuat simbol seni tampak hidup. Ekspresi adalah ibarat roh yang menjiwai simbol seni. Ekspresilah yang menghadirkan subjektivitas seniman, sehingga simbol seni tidak jadi beku, tetapi dapat berbicara pada orang lain.

Jadi ekspresi memungkinkan suatu komunikasi dengan orang lain. Karena seni bukan suatu imajinasi yang elit atau tertutup, melainkan justru untuk membuka diri. Berekspresi sifatnya intensional, artinya mengarah keluar, membuka diri. Arah keluar inilah yang menjadi tujuan ekspresi. Jadi, ekspresi menuntut adanya wujud konkret agar seni tidak berhenti sebagai imajinasi saja. Sebagai contoh, seorang pelukis tidak mungkin hanya menyimpan karya-karyanya, tetapi juga perlu untuk memperlihatkannya pada orang lain.
Ekspresi yang mengarah keluar iu tidak dimaksudkan Langer sebagai bentuk komunikasi berkutub dua, karena ekspresi tidak mengarah ke tujuan tertentu. Menurut Langer (dalam Ali, 2011:120) karya seni merupakan ekspresi perasaan yang spontan, artinya ada unsur ketidaksadaran dalam seni. Jadi seni dapat dimasukkan ke dalam kategori mimpi, karena sifat ilusinya yang tidak sadar, spontan dan bebas. Namun dalam seni, berkat unsur ekspresi, ilusi tersebut dapat diungkapkan dan disaksikan oleh orang lain, sedangkan pada mimpi tidak.

Ekspresi seni berbeda dengan ungkapan emosional atau perasaan yang menggejala. Misalnya, seseorang yang sedang marah, sedih atau gembira, terlihat dari ekspresi muka atau tingkah lakunya. Menurut Langer, ekspresi seni bukanlah ekspresi diri. Karena ekspresi seni menawarkan sebuah nilai keindahan dan memperhalus sifat komunikasi menjadi suatu persentuhan rasa yang kental. Artinya, ekspresi seni dapat menularkan pengalaman subjektif seniman pada orang lain. Jadi, sebenarnya seni memiliki nilai edukatif. Namun nilai ini tidak bersifat langsung, karena sifatnya yang halus dan simbol-simbolnya yang khas.

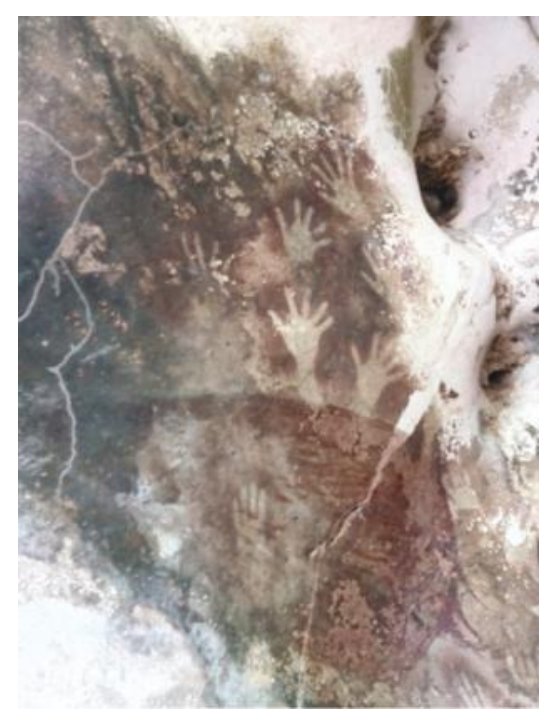

Gambar 1. Lukisan cap tangan dan hewan di Gua Leang-Leang 

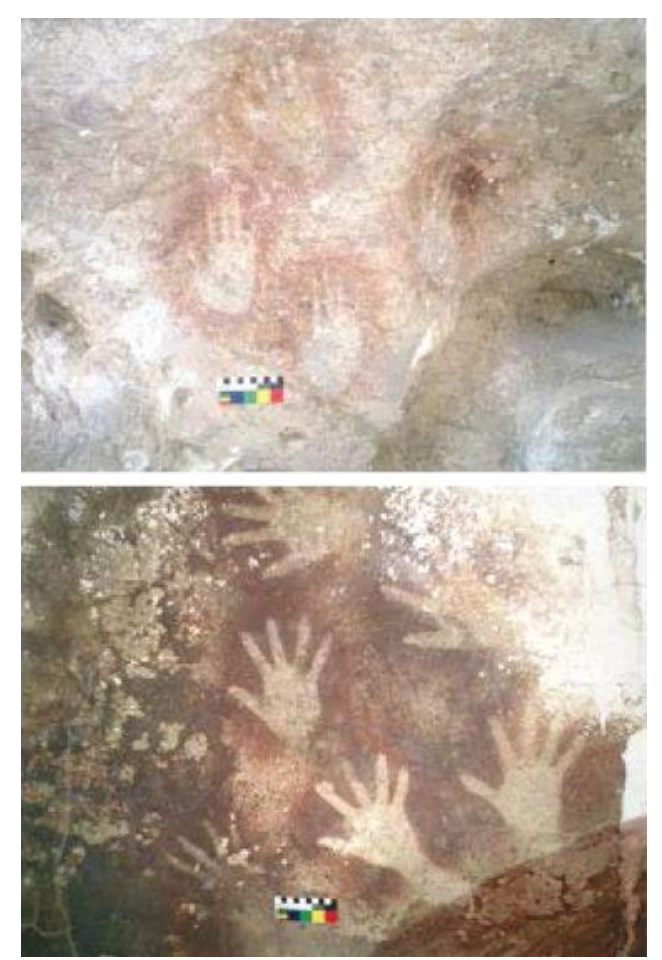

Gambar 2. Bentuk Gambar Telapak Tangan di Lukisan Gua Leang-Leang

\section{SEBAGAI SIMBOL EKSPRESIF}

Lukisan gua Leang-Leang yang diciptakan oleh manusia prasejarah kurang lebih 30-an ribu tahun lalu telah menjadi sebuah karya yang menandakan peradaban manusia prasejarah. Karya lukis prasejarah gua Leang-Leang telah memperlihatkan estetis yang dimiliki oleh manusia zaman itu. Mereka telah mempunyai talenta, telah mampu mendeformasi imajinasi ke dalam bentuk karya seni lukis. Walau tidak benar-benar realis namun hal itu telah menunjukkan apa yang ada dalam realitas. Dalam lukisan gua Leang-Leang ini, telah ada teknik pewarnaan dan perspektif, walau dalam batas minimal. Hal itu merupakan suatu ungkapan estetis yang alami.

Lukisan gua Leang-Leang yang menggambarkan telapak tangan dan hewan babi rusa dengan berlatar belakang merah, merupakan sebuah penanda bahwa mereka "ada" diwilayah itu. Lukisan telapak tangan merupakan bentuk eksistensi mereka. Eksistensi (existence) (latin, existere dari kata keluar, dan sister: tampil; yang berarti: muncul, ada memiliki keberadaan secara nyata). Eksistensi dapat dilawankan dengan being (ada), yang sering dilawankan dengan esensi. Esensi lebih kepada hakiki (dunia roh), sedangkan eksistensi sebagai subjek manusia yang berada dalam dunia. Jadi lukisan telapak tangan di gua merupakan bukti bahwa manusia prasejarah (purba) menyatakan dirinya "ada" sebagai makhluk yang bereksistensi, yang mempunyai identitas.

Sedangkan lukisan hewan (babi rusa) merupakan bagian dari alam yang menurut manusia prasejarah sebagai ekosistem yang perlu dijaga dan dihormati. Disamping dijadikan buruan untuk kebutuhan makan, hewan menurut mereka merupakan bagian dari eksistensi mereka. Mereka menyadari bahwa hidupnya bukan hanya dunia semata manusia, tetapi ada hewan dan alam raya.

Sebagai makhluk bereksistensi yang ditunjukkan manusia prasejarah dengan melukis di dinding gua, dengan menggambarkan telapak tangan dan hewan merupakan suatu bentuk simbol ekspresi bagi persepsi masyarakat pendukungnya lewat pencitraan. Hal yang diekspresikan adalah perasaan manusia prasejarah yang mampu menangkap phenomena alam yang sulit diungkapkan. Bentuk ekspresi inilah disebut karya seni yang merupakan proyeksi dari "gejolak perasaan".

Ekspresi karya seni (lukisan) yang diciptakan oleh manusia prasejarah ini terjadi sebuah komunikasi dengan orang lain (anggota masyarakatnya), karena karya seni yang diciptakan manusia prasejarah bukan suatu imajinasi yang tertutup melainkan justru membuka diri. Artinya hasil ekspresi yang diciptakan bukanlah milik pribadi tapi mampu memberi pesan atau makna kepada anggota masyarakat yang lain. Ini dapat terlihat dengan pembuatan telapak tangan dan babi rusa, dimana memberi pesan atau makna bahwa inilah hewan yang menjadi target buruan mereka dalam memenuhi kehidupannya selain juga hewan itu sebagai ekosistem yang harus dijaga dan dihormati. Berekspresi sifatnya intensional, artinya mengarah keluar, membuka diri. Arah keluar inilah yang menjadi tujuan ekspresi. Jadi menurut Langer, ekspresi menuntut adanya 
wujud konkret agar seni tidak berhenti sebagai imajinasi saja.

Ekspresi yang mengarah keluar itu tidak dimaksudkan Langer sebagai bentuk komunikasi berkutub dua, karena ekspresi tidak mengarah ke tujuan tertentu. Menurut Langer, karya seni merupakan ekspresi perasaan yang spontan, artinya ada unsur ketidaksadaran dalam seni. Jadi seni dapat dimasukkan ke dalam kategori mimpi, karena sifat ilusinya yang tidak sadar, spontan dan bebas. Namun dalam seni seperti lukisan yang diciptakan manusia prasejarah, berkat unsur ekspresi, ilusi tersebut dapat diungkapkan dan disaksikan oleh orang lain, sedangkan pada mimpi tidak. Dapat dikatakan bahwa, sebenarnya lukisan prasejarah memiliki nilai edukatif bagi masyarakat pendukungnya.

\section{SEBAGAI SIMBOL PRESENTASIONAL}

Teori estetika Langer berhubungan dengan dengan teori simbol yang dikemukakannya. Langer membedakan antara simbol yang diskursif (discursive symbol) dan simbol presentasional atau penghadir (presentational symbol). Langer menyimpulkan bahwa simbol tidak hanya dipergunakan dalam logika saja, yakni logika simbol, tetapi juga dalam bidangbidang lain seperti seni, teori mimpi, ilmu kimia dan statistic yang merupakan bidang-bidang ilmu yang mempergunakan simbol-simbol. Diskursivitas seperti yang terdapat dalam pemakaian simbol seperti di atas, tidak selalu menjadi prinsip dalam pemakaian simbol pada bidang-bidang lain.

Langer mulai memikirkan perlunya pemahaman simbol tanpa suatu kontruksi yang mendetail dan logika murni. Akhinya Langer menemukan suatu pemahaman simbol secara intuisi langsung, inilah yang disebutnya sebagai "simbol presentasional" yang merupakan penolakan simbol diskursif pada logika modern. Simbol seperti inilah yang terdapat dalam kreasi seni. Memahami karya seni tidak dengan suatu struktur yang dibangun oleh unsure-unsur menurut aturan yang kaku. Karya seni harus dipahami dengan kesatuan yang bulat dan utuh tanpa harus diuraikan lagi bagian perbagian yang lebih kecil. Karya seni adalah sesuatu yang konkrit, sesuatu yang ada keunikannya, sesuatu yang lebih perwujudan fisiknya. Lukisan sebagai karya seni adalah merupakan suatu active termination, buah dari transformasi simbolik dari pengalaman. Penciptaan lukisan bermula dari kegiatan yang sifatnya ekspresif sehingga tidak bisa dinilai dari segi rasional atau praktis.

Lukisan sebagai simbol presentasional atau penghadir, terdapat makna yang lebih luas dan mendalam di balik lukisan itu sendiri, dalam artian lukisan dipahami bukan sekedar lukisan untuk lukisan. Lukisan merupakan simbol ekspresi senimannya, simbol yang oleh senimannya sendiri sulit untuk mengungkapkannya, dikarenakan dari ketidakpahamannya akan kekuatan dan dahsyatnya alam, sehingga kekuatan dan kedahsyatan alam yang tidak dimengertinya itu menjadi sebuah material yang meniru tangkapan logikanya.

Lukisan harus dipandang sebagai simbol yang utuh, pemahamannya melalui intuisi langsung. Pemahaman bukan melalui kontuksi atau susunan unsur-unsur pembentuk lukisan, apakah itu materialnya, warna, garis, bentuknya. Walaupun sebenarnya unsure-unsur pebentuk lukisan itu sendiri terdiri dari beberapa simbol yang lebih khusus sifatnya, tetapi pemahamannya bukanlah berdasar dari unsureunsurnya, melainkan kesatuan dari unsur-unsur itu membentuk simbol yang lebih baru sifatnya. Makna simbol lukisan (prasejarah) di gua LeangLeang memiliki makna yang justru dibentuk oleh kesatuan unsur intrinsik dan eksintriknya. Mitos berhasil membentuk pengertian makna dari patung itu sendiri. Makna lukisan sebagai simbol bersumber dari cerita mitos yang terkontaminasi atau merasuk saraf-saraf pikiran masyrakatnya. Mitos memberikan suatu orientasi dalam kehidupan manusia prasejarah dan merupakan simbolisasi ketengangan pergumulan hidup manusia untuk mengartikan dunia dan dirinya sendiri yang misterius.

Kehadiran lukisan pada masyarakat prasejarah di gua Leang-Leang adalah karena kebutuhan religious magis, lukisan menjadi simbol dari rambu-rambu moral dan tata ibadah. Lukisan mampu menjadi alat kontrol dalam 
setiap aktivitas warga masyarakat prasejarah dalam melakukan perburuan. Lukisan prasejarah diyakini memiliki jiwa yang dianggap lebih super daripada manusia sendiri. Manusia seakan tidak kuasa serta tunduk atas lukisan sesuai dengan pengertian dan ketidakpahamannya akan lukisan itu.

\section{SEBAGAI VIRTUAL SPACE}

Lukisan adalah bentuk fisis tentang sesuatu yang metafisis. Lukisan adalah virtual space (ruang yang sungguh) dari kekuatan atau daya yang metafisis. Suatu bentuk nyata dari ide-ide semu, yang mampu menjelaskan sesuatu "yang ada belum terpahami" dengan simbol-simbol.

Lukisan prasejarah gua Leang-Leang adalah virtual space, atau gambaran dari mitos-mitos yang dipercayai dalam kehidupan masyarakatnya. Konsepsi mitos yang telah merasuk dalam setiap syaraf-syaraf masyarakatnya di visiualkan dengan bentuk lukisan meliputi garis, bentuk, dan pewarna yang mengimitasi realitas secara subjektif. Namun sesungguhnya bukan pada lukisan itu terletak kekuatan dan kemagisan cerita mitos yang hidup didalam masyarakatnya, melainkan pada tanggapan dan sangkaan-sangkaan dalam pikiran masyarakat pendukungnya itu sendiri. Lukisan hanyalah bentuk visual semu dari konsepsi mitos yang dipercaya. Lukisan adalah virtual space dari ungkpan perasaan atas konsepsi-konsepsi itu.

Eksistensi virtual bukanlah sesuatu yang tidak nyata dimana manusia menghadapinya, serta betul-betul merasakannya, bukan bermimpi atau mengkhayalkannya. Ini mengindikasikan proses pengeluaran citra dari kedalam bathin, bagi diri sendiri atau orang lain yang melihatnya, yaitu menyajikan suatu peristiwa yang bersifat subjektif dalam simbol yang bersifat objektif. Lukisan adalah sesuatu yang mempertunjukkan pancaran dari alam bathin sang penciptanya, suatu presentasi objektif dari realita subjektif dan bahwa itu semua bisa melambangkan sesuatu dari kehidupan bathinianya. Citra yang tercipta memiliki pola serta elemen-elemen seperti pada gejolak perassaan penciptanya. Namun citra yang terwujudkan tersebut, adalah suatu fenomena yang murni, yang bersifat objektif. Bagaimanapun suatu bentuk lukisan, tetap merupakan objektifikasi kehidupan subjektif, dan begitulah adanya pada setiap karya seni. Lukisan merupakan gambar virtual atau gambar maya dari apa yang menjadi konsepsi-konsepsi yang diketahui penciptanya. Gambar virtual adalah presentasi sebenarnya tentang perasaan.

\section{SEBAGAI SIMBOL SENI}

Dalam pembahasan seni dan simbol, Langer dengan tegas membedakan antara simbol seni dan simbol di dalam seni. Langer menyimpulkan bahwa perbedaan antara simbol seni dan simbol digunakan di dalam seni, bukanlah hanya pada fungsinya, namun juga dari macamnya yang ada. Simbol-simbol yang ada dalam seni merupakan pengertian yang umum, walaupun dari derajat kompleksitasnya, dari kewajarannya yang paling bersahaja sampai dengan paling ekstrim, dari yang tersendiri sampai dengan yang palig merasuk secara dalam, dan dari yang paling jelas sampai dengan yang berlebihan olahan ketegangannya. Simbol-simbol dalam seni lukisan prasejarah di Gua Leang-Leang memberikan kandungan berbagai arti seperti: kesucian, kekuatan, kebersamaan, pengharapan, kegigihan, dan lain sebagainya. Makna simbol pada lukisan prasejarah bukan terletak pada elemen-elemen yang menciptakan serta mengartikulasikan bentuk organisnya, sebagai mana pokok persoalan yang dikandungnya.

Menurut Langer, simbol seni merupakan simbol dalam pengertian yang khusus, karena menyajikan beberapa fungsi simbolik, walaupun tidak seluruhnya; khususnya, tidak berarti sesuatu yang lain, atau menunjuk pada sesuatu yang terpisah dengannya. Menurut defenisi "simbol" yang biasa berlaku, suatu karya seni sebaiknya tidak digolongkan sebagai simbol semata-mata.

Seni dan karya seni adalah dua bahasan yang berbeda. Jika seni dikatakan suatu nilai, maka karya seni atau benda seni adalah pengembangnya. Seni ada jika ada pengembangya. Seni dan nilai tidak tergantung pada pengembang, ia lebih dulu ada daripada 
pengembangnya, sehingga disebut karya seni. Seni tidak ada untuk dirinya sendiri, ia membutuhkan pengembang untuk berada. Karya seni seperti lukisan prasejarah di gua Leang-Leang adalah simbol seni itu sendiri. Jadi karya seni adalah pengembang seni itu sendiri. Manusia membutuhkan pengembang untuk dikreasikan guna menyampaikan konsepsikonsepsi seni yang diketahuinya. Objek realitas dikreasikan sesuai dengan suasana hati atau emosinya pada saat itu. Kosepsi-konsepsi manusia diabstraksikan lewat media, media itu sendirilah menjadi simbol seni. Dengan demikian, lukisan merupakan bentuk simbol dalam penampilan yang lain daripada yang dihasilkannya. Bentuk ekspresi, atau simbol seni yang dimaksudkan adalah karya seni itu sendiri yang dapat dilihat dengan kasat mata. Karya seni (lukisan prasejarah) menampilkan presentasi yang sebenarnya tentang suatu perasaan, bukan suatu isyarat yang menunjuk pada perasaan tersebut.

Manusia prasejarah sudah pasti tidak tahu tentang seni, tetapi yang jelas mereka menangkap alam realitas karena didorong ungkapan perasaannya mengaktualisasikan apa yang diketahuinya dan apa yang dipahaminya tentang alam pada suatu pengembang seperti pewarna dan batu. Pengembang inilah yang dikatakan lukisan, sedangkan aktivitas dan kreasi manusia mengungkapkan ekspresinya lewat pengembang itulah dikatakan seni. Jadi lukisan adalah simbol seni itu sendiri.

\section{KESIMPULAN}

Lukisan prasejarah gua Leang-Leang yang diciptakan oleh manusia prasejarah, ini merupakan bukti kalau seni dan manusia tidak pernah lepas dari kehidupan. Lukisan yang berusia 30-an ribu tahun ini merupakan simbol dari konsep-konsep teologi, antrophologi, sosiologi dan estetik dari segala aktifitas hidup manusia prasejarah.

Lukisan prasejarah merupakan simbol seni, simbol dari segala konsepsi yang transenden. Dasar kreasi seni adalah apa yang disebutnya sebagai "ilusi primer". Ilusi primer adalah semacam latar belakang atau layar di atas mana bisa diproyeksikan macam-macam bentuk seni sebagai "ilusi sekunder". Oleh sebab itu, lukisan disebut Langer sebagai "ruang yang sungguh" (virtual space). Konsepsi mitos yang telah merasuk dalam setiap syarafsyaraf masyarakatnya divisualkan dalam bentuk lukisan. Lukisan mengimitasi realitas secara subjektif, maka disebut objektifitas dari subjektifitas.

Lukisan prasejarah merupakan simbol ekspresi dan bentuk hidup (living form). Lukisan prasejarah adalah suatu bentuk simbol ekspresi yang diciptakan bagi persepsi masyarakat pendukungnya lewat pencitraan. Hal yang diekspresikan adalah perasaan manusia prasejarah yang mampu menangkap fenomena alam yang sulit untuk diungkapkan.

\section{DAFTAR PUSTAKA}

Ali, Matius. 2009. Estetika: Sebuah Pengantar Filsafat Keindahan. Tangerang: Sanggar Luxor.

Ali, Matius. 2011. Estetika: Pengantar Filsafat Keindahan. Tangerang: Sanggar Luxor.

Cassirer, Ernst. 1990. Manusia dan Kebudayaan: Sebuah Esei Tentang Manusia. Diindonesiakan oleh Alois A. Nugroho. Cet. Kedua. Jakarta: Gramedia.

Dillistone, F.W. 2002. The Power of Symbols. Yogyakarta: Pustaka Filsafat.

Eliade, Mircea. 1991. The Myth of the Eternal Return or, Cosmos and History. New Jersey: Princenton University Press. Princeton.

Fashri, Fauzi. 2007. Penyingkapan Kuasa Simbol. Yogyakarta: Juxtapose.

F. X. Widaryanto. 2006. Problematika Seni. Terjemahan. Bandung: STSI Bandung.

Koentjaraningrat. 1987. Sejarah Teori Antropologi. Jakarta: UI Press.

Langer, Susanne Knauth, 1957, Problems of Art: Ten Philosophical Lecthures Edition 6. New York: Charles Scribner Sons.

Langer, Susanne Knauth. 1973, Feeling and Form. New York: Charles Scribner Sons.

Langer, Susanne Knauth. 1976, Philosophy in A New Key: A Study in the Symbolism of Reason, Rite and Art. Third Edition. 
Cambridge, Massachusetss: Harvard University Press.

Saragi, Daulat. 2007. "Dimensi Simbolis Patung Primitif Batak, Kajian Menurut Konsep Estetika Susanne Knauth Langer", Disertasi SPS UGM.

Sutanto, P.S Hary. 1987. Mitos Menurut Mircea Eliade. Cet. Pertama. Yogyakarta: Kanisius.
Sumardjo, Jakob. 2010, Estetika Paradox. Bandung: Sunan Ambu Press.

Sachari, Agus. 2002. Estetika: Makna, Simbol, dan Daya. Bandung: ITB Press.

The Liang Gie, 1996. Filsafat Seni. Yogyakarta: Pusat Belajar Ilmu Berguna (PBIB).

Triguna Y. G. Bagus, Ida. 2000. Teori tentang Simbol. Bali: Widya Dharma.

Turner, Jane. 1996. The Dictionary of Art. 18 Volumes. London: Macmillan Publisher Limited. 